case to what consequences coercive means lead. For a very trustworthy attendant in the case of a female patient, who with great deftness was in the habit of divesting herself of her strait-jacket, had caused an iron collar like a dog's to be made for her. Another important point was brought to light, as Meyer himself related, by the experiences of the old lunacy department of the general hospital; namely, that the public need not be held aloof so anxiously from mental cases as used formerly to be thought necessary. On Sundays all the rooms of the lunacy department were filled with visitors, who did not stare at the patients with curious looks, but brought them a number of presents. There never occurred any disturbance from this; on the contrary, there was the advantage that the public did not harbour any suspicion against the institution. Meyer remained true to these convictions. At the present time in Göttingen such visits to the patients are allowed. By this means the public are educated, and the institution is divested of mystery, so that there subsists no difference in this particular between it and any other hospital.

That a man like Meyer, under the hygienic conditions that were prominent in the Hamburg Lunatic Department, entered into the design of a new building for the insane patients, goes without saying. Already in 1864 was he able to migrate with the patients committed to his care into an asylum built quite to his own mind, and arranged for the non-restraint treatment, at Friedrichsberg. In 1861 he had previously, in the course of a prolonged sojourn, carefully studied the immense progress of English treatment. But at Friedrichsberg he was not destined long to labour. In the year 1866 he accepted a call as Professor in the University and Director of the Lunatic Asylum of Göttingen, to open the first German clinic for Psychiatry in a building specially constructed for the purpose. In this position, despite of various inducements, he remained, equally beloved and valued as Clinical Teacher as well as Director and Officer in the Provincial Asylum.

In the year 1867 Meyer, in conjunction with Griesinger, established the Archives of Psychiatry. The works of Meyer range over the whole region of Psychiatry. In addition to works relating more to the social side of Psychiatry, the care of the insane, the management of asylums, and such like, we find exact pathologicoanatomical investigations and excellent clinical studies. These are to be found in great number-in Virchow's Archives, the Charité Annals, the Archives of Psy. chiatry, etc.

That the advice of a man so experienced and so rich in projects of reform was frequently claimed in the building of insane asylums, scarcely needs to be mentioned. Meyer drew up the programme of numerous institutions, or cooperated in their projection. Among these were Hamburg, St. Urban, and Marburg. He was elected an honorary member of the Medico-Psychological Association in 1867 .

Professor Meyer died in October, 1899 , in his seventy-third year, lamented by his colleagues throughout Germany. We are indebted to Dr. Cramer for the sketch of his life above presented.

\title{
Dr. Bouchereau.
}

Dr. Louis Gustave Bouchereau, who died the 22nd of February, was born the 2oth of June, 1835, at Montrichard, in the mild and pleasant country of Touraine, the garden of France and cradle of such illustrious men as Georget, Bretonneau, Trousseau, Moreau de Tours, and Baillarger. He studied medicine in Paris. Externe of the hospitals in 1859, interne in 1863, he was the pupil of Jean Pierre Falret, Baillarger, Charcot, and Vulpian. He obtained the doctor's degree in 1866; the subject of his thesis being "Hémiplégies anciennes." In the same year he was elected, conjointly with Dr. Magnan, as médecin du service de répartition at the Ste. Anne asylum, and held this post till 1879, when he became superintendent of the female wards. During the war of $1870-71$ he served in a field hospital, was wounded at the battle of Chatillon, and received, as a reward for his gallant conduct and devotedness, the badge of the Legion of Honour.

Bouchereau was elected as a member of the Société Médico-Psychologique of Paris, on the 27th of November, 1871, and became President in 1891. In 1866 he was elected secretary by the Association mutuelle des médecins alienistes de France. The object of that association, which was recognised $d^{\prime}$ utilité publique XLVI. 
by an Imperial decree in 1866 , is to help those members who might be in distress, and to aid the widows and orphans of alienists. Since its foundation the presidents have been Baillarger, Blanche, Armand, Semelaigne and Meuriot; the treasurers have been Lunier and Mitevié (a great-nephew of Esquirol), Legrand du Saulle ; the first secretary was succeeded by Brierre de Boismont, Mitivie and Bouchereau.

Bouchereau was frank, sincere and modest. Every one who came into contact with this kind and loyal gentleman rapidly formed a deep affection for him. His patients were so devotedly attached to the good doctor, that a palsied woman earnestly prayed to be carried into the death chamber to view his features once more.

Bouchereau entertained great friendship with the late Dr. Hack Tuke, who, during his holidays in 1893 , was his guest at Montrichard.

It may be said of Bouchereau, as of Tuke, that he left a wide circle of sorrowing friends and no enemies.

Renḱ. Semelaigne.

\section{NOTICES BY THE REGISTRAR.}

\section{Certificate of Proficiency in Mental Nursing.}

The next examination will be held on Monday, the 7 th day of May, 1900, and candidates are earnestly requested to send in their schedules, duly filled up, to the Registrar of the Association, not later than Monday, the 9th day of April, 1900 , as this is the last day upon which, under the rules, applications for examination can be received.

\section{Certificate in Psychological Medicine.}

The next examination will be held on July 19th, 1900 .

The examination for the Gaskell prize will take place at Bethlem Hospital on the 20 th of the same month.

\section{THE PRIZE DISSERTATION.}

Although the subjects for the essay in competition for the Bronze Medal of the Association are not limited to the following, in accordance with custom the President suggests-

1. Developmental general paralysis.

2. The surgical treatment of epilepsy and epileptiform seizures.

3. The effect of influenza on the production of states of mental unsoundness.

The dissertation for the Association and prize of Ten Guineas must be delivered to the Registrar, Dr. Benham, City of Bristol Asylum, before May 3oth, I900, from whom all particulars may be obtained.

By the rules of the Association the Medal and Prize are awarded to the author (if the Dissertation be of sufficient merit) being an Assistant Medical Officer of any Lunatic Asylum (public or private), or of any Lunatic Hospital in the United Kingdom. The author need not necessarily be a member of the Medico-Psychological Association. Due notice of the exact dates will appear in the medical papers. Further particulars respecting the various examinations of the Association may be obtained from the Registrar, Dr. Benham, City Asylum, Fishponds, Bristol.

\section{NOTICES OF MEETINGS.}

Medico-Psychological Association.

General Meeting.-The next General Meeting will be held on Thursday, 1oth May, 1900, in the Rooms of the Association, II, Chandos Street, W., at 4 P.m.

At this meeting the following papers will be read:

1. "The New Psychology," by H. Maudsley, M.D., F.R.C.P.Lond. 